\title{
Striving for Quality Education: The Right to Education as a Socio-Economic Right
}

\author{
Grace Mbajiorgu
}

Faculty of Management and Law, School of Law, University of Limpopo, South Africa gracedg.mafunganyika@gmail.com

Thinavhudzulo Mafumo

Faculty of Humanities, School of Education, University of Limpopo, South Africa

Thinvhudzulo.Mafumo@ul.ac.za

\section{Doi:10.5901/mjss.2014.v5n8p302}

\section{Abstract}

\begin{abstract}
The article focuses on the realisation of the right to education in South Africa. The State has an obligation in terms of section 29 of the Constitution of the Republic of South Africa of 1996 to ensure the progressive realisation of the right to basic education. The State is also obliged to take reasonable measures, to ensure that the right to education is progressively available and accessible at tertiary level. A historical approach is adopted in the discussion; the great disparities within the South African education system created by the apartheid regime are highlighted as basis for the discussion. The article also examines the States' international obligations and commitments under international in the realisation of the right to education. Finally, the article examines the measures that the South African government has taken to comply with its constitutional obligations to create an equal education system for all. In order to examine the measures taken by the State to realise the right to education, the article analyses existing legislation, policies, and judicial decisions.
\end{abstract}

Keywords: Right to education, Availability, Accessibility, Progressive realisation, Learner-oriented

\section{Introduction}

When the National party came into power in 1948 it started with the conceptualisation of the introduction of Bantu education (Mphahlele \& Mminela, 1997:60). On the 19 January 1949, His Excellency, the Governor - General, appointed a commission to go into the question of introducing Bantu Education. The first term of reference on this commission was the formulation of the principles and aims of education for the natives as an independent race, in which their past and present, their inherent racial and distinctive characteristics and their aptitude and their needs under ever - changing social conditions are taken into consideration (Franz, 1956:5-8). The commission's investigations lead to the introduction of Bantu education in 1953.

Thereafter, the Bantu Education Act 49 of 1953 was passed to formalise Bantu education. This is how the racial separated education was conceptualised and strengthened (Mphahlele \& Mminela, 1997:60-61; Hartshorne, 1992:36-37). From 1954 - 1955 black teachers and learners protested against Bantu Education. From these protests the African Education Movement was formed to give alternative education. In 1959 the Extension of University Education Act 45 of 1959 was passed which made provision for the establishment of racially exclusive universities for black South Africans. During this period black students were no longer attending white universities freely (Christie, 1991:56).

This achieved one of the main aims of the apartheid education system which was to build up awareness of racial differences (Christie, 1991:140). Apartheid education in South Africa was designed to keep different racial groups separate. Separate schools were part of an overall plan for social, economic, and political development of apartheid. Separate schooling for different racial groups made learners to know separation and inequalities along the lines of race, language, and culture (Christie, 1991:141).

According to Deegan (Deegan, 2001:23) the barriers such as culture, race and language were some of the hallmarks of apartheid education system which lead to the beliefs that Africans and Whites have different cultures and can never live together in peace. According to Christie the belief in inherently different cultures of Blacks and Whites lead to schools for Whites only and Blacks only. Language was also used as a barrier because there were schools for white Afrikaans speaking learners only, white English speaking learners, and schools for the blacks according to their different languages such as Venda, Zulu, Tsonga, Xhosa, and Ndebele etc (Christie, 1991:56-57). 
In 1963 the Coloured Person's Education Act was passed. The coloured education was controlled by the Department of Coloured affairs. During 1965 the Indian Education Act was passed. Indian education was placed under the Department of Indian affairs.

In 1969 black students (African, Coloured, and Indian) organization called South African Students Organization (SASO) was formed. The formation of SASO was followed by the Soweto June 1976 uprisings led by the African youth who were continuing with the struggle against the apartheid policy of separate education systems in South Africa as well as great dissatisfaction with the Bantu education.

Following the 1976 uprisings the then government passed the African Education Act to replace the Bantu Education Act of 1953 in response to the uprising. African Education was placed under the Department of Education and Training (Harber, 1997:142). In 1980 the De Lange Commission was set up to conduct an in depth investigation into the South African education system and to make recommendations for an education policy for South Africa. The De Lange report of 1981 recommended a single department of education for all South Africans irrespective of race, education of equal quality for all, and changed schooling structure.

In 1983, the then government accepted the De Lange Commission's guiding principles but rejected the major recommendation of a single education department for all races. The National Policy for General Education Act was passed in 1984. This Act brought the education structures in line with the 1983 Constitution of the Republic of South Africa (Sithole, 1999:42). Different Departments of Education and Culture were set up for whites, coloureds, and Indians in 1984. Education for Africans remained under the Department of Education and Training. The education system in the homelands fell under its own departments under the management of Department of Education and Training (Harber, 1997:142).

The Soweto Parents Crisis Committee (SPCC) was formed in 1985 to address the education crisis caused by the apartheid education. In 1986 the National Education Crisis Committee (NECC) was formed to further the intention and interest of (SPCC) which were to address the crisis caused by the Bantu Education system (Sithole, 1998: 44-45).

The basis of the opposition against the apartheid education system was because the separate education system also entrenched patterns of social class discrimination.( Hartshorne, 1992:36-37). Education for Africans during this period remained segregated and unequal. White and Indian education were generally well -endowed. Coloured education was also in a perilous state while education for the blacks was far worse off. In the various school systems there existed a racial hierarchy of unequal provision to which in- school children were subjected. Black learners attended on average four years of schooling which prepared them to acquire a functional level of literacy and numeracy that was important for them to do semi - skilled work. State funding for black education was inadequate and very limited, the main consequence of which was low - level quality schooling for the blacks (Fataar, 1997:341).

However, with the advent of the new constitutional dispensation, the right to education was entrenched in the Bill of Rights. This meant that everyone in South Africa had the right to equal education. This further placed an obligation on the state to ensure that the quality of education at schools met acceptable curricula standards.

\section{Section 29 as a Justiciable Human Right in International Law}

Socio-economic rights are rights that require the state to take positive measures to enable people to access certain basic needs (resources, opportunities, and services) necessary for human beings to lead a dignified life (Khoza, 2007:20). According to Liebenberg and Goldblatt (Liebenberg and Goldblatt, 2007: 335-361) socio-economic rights has as one of its aims to bridge the social disparities between the privileged and the poor.

Liebenberg and Goldblatt (Liebenberg and Goldblatt, 2007:339) argue that, "an approach to the interpretation of equality and socio-economic rights that acknowledges the interrelationship between these rights is also more likely to be responsive to the reality that the most severe forms of disadvantage are usually experienced as a result of an intersection between group-based forms of discrimination and socio economic marginalisation".

As a result the state has an obligation to ensure the progressive realisation of these rights in accordance with national, regional and international law.

As a signatory to the International Covenant on Economic Social and Cultural Rights, and having ratified the Convention on the Rights of the Child, Universal Declaration on Human Rights and African Charter on Human and Peoples' Rights, the South African government is obliged to comply with its international commitments. This compliance includes the enactment of legislative frameworks aimed at discharging its duties as outlined in section 29(1)(a) and(b) of the Constitution. Section 29(1) provides that everyone has the right-(a) to a basic education, including adult basic education, and (b) to further education, which the state, through reasonable measures, must make progressively available and accessible. 
Article 13(1) of the ICESCR provides that state parties recognise the right of everyone to education, further that they agree that education shall be directed to the full development of the human personality and the sense of its dignity, and shall strengthen the respect for human rights and fundamental freedoms. Article 13(2) provides further that in ensuring the full realisation of the right to education, primary education must be compulsory and free, secondary education in its different forms, including technical and vocational secondary education, shall be made generally available and accessible to all by every appropriate means, and in particular by the progressive introduction of free education and higher education shall be made equally accessible to all, on the basis of capacity, by every appropriate means, and in particular by the progressive introduction of free education.

In South Africa numerous legislative frameworks and policies have been enacted to give effect to right to education as entrenched in section 29 of the Constitution inter alia , the Schools Act 84 of 1996 as amended, National Education Policy Act 27 of 1996 (which lead to the enactment of National Policy Framework for Teacher Education and development in South Africa), the White Paper on Reconstruction and Development Gazette 16085, Notice 1954, 23 November 1994 (the RDP), Plan of Action Improving access to free and quality basic education for all, National Plan for Higher Education in South Africa, Education White Paper 3- A Programme for Higher Education Transformation, the Education White Paper 4-A programme for the Transformation of Further Education and Training Government Gazette No. 19281, Vol 339, 25 September 1998 and White Paper on Education and Training Notice 196 of 1995 (the White Paper) amongst others.

Due to the limited scope of this article only the White Paper on Reconstruction and Development and the White Paper on Education and Training will be discussed in detail below. Brief references to other legislative frameworks will be made where necessary. However, it is apparent from the titles of the above-mentioned legislative frameworks that the sole purpose for their promulgation was to give effect to the right to education as entrenched in section 29 of the Constitution. This is also consistent with articles 28 and 29 respectively of the Convention on the Right of the Child. Article 28 (1) provides that states parties recognize the right of the child to education and with a view to achieving this right progressively and on the basis of equal opportunity, they shall, in particular;

(a) make primary education compulsory and available free to all;

(b) encourage the development of different forms of secondary education, including general and vocational education, make them available and accessible to every child, and take appropriate measures such as the introduction of free education and offering financial assistance in case of need;

In the regional context, article 11 of the African Charter on the Rights and Welfare of the Child (ACRWC) echoes the sentiments of article 29 of the CRC. Article 25 of the African Charter which provides that state parties to the Charter shall have the duty to promote and ensure through teaching, education and publication, the respect of the rights and freedoms contained in the present Charter and to see to it that these freedoms and rights as well as corresponding obligations and duties are understood.

Moreover, article 26(1) of the Universal Declaration on Human Rights (UDHR) provides that everyone has the right to education. Education shall be free, at least in the elementary and fundamental stages. Elementary education shall be compulsory. Technical and professional education shall be made generally available and higher education shall be equally accessible to all on the basis of merit. To emphasise the importance of the right to education as a socio-economic right, the Committee on Economic, Social, and Cultural rights implemented General Comment No. 13 The right to education (Art.13): 12/08/1999 E/C.12/1999/10 (General Comments) Twenty-first session, 1999.

In paragraph 1 the General Comment provides that education is both a human right in itself and an indispensable means of realizing other human rights. As an empowerment right, education is the primary vehicle by which economically and socially marginalized adults and children can lift themselves out of poverty and obtain the means to participate fully in their communities. Education has a vital role in empowering women, safeguarding children from exploitative and hazardous labour and sexual exploitation, promoting human rights and democracy, protecting the environment, and controlling population growth. Increasingly, education is recognized as one of the best financial investments States can make. But the importance of education is not just practical: a well-educated, enlightened, and active mind, able to wander freely and widely, is one of the joys and rewards of human existence.

A close analysis of the above paragraph brings the right to education to par with other socio-economic rights such as the right to housing, health, and safe and healthy environment. The basis of our contention is based on the fact that similarly to all other socio-economic rights the right to education is aimed at the betterment of the citizen's quality of life (RDP: 3.3.1.).

As a result, the General Comment also sets out four principles as envisaged in article 13(2) of the ICESCR on how state parties can give effect to this right. These principles are namely; 
(a) Availability - functioning educational institutions and programmes have to be available in sufficient quantity within the jurisdiction of the state party. What they require to function depends upon numerous factors, including the developmental context within which they operate; for example, all institutions and programmes are likely to require buildings or other protection from the elements, sanitation facilities for both sexes, safe drinking water, trained teachers receiving domestically competitive salaries, teaching materials, and so on; while some will also require facilities such as a library, computer facilities and information technology.

(b) Accessibility - educational institutions and programmes have to be accessible to everyone, without discrimination, within the jurisdiction of the state party. Accessibility has three overlapping dimensions

- Non-discrimination - education must be accessible to all, especially the most vulnerable groups, in law and fact, without discrimination on any of the prohibited grounds.

- Physical accessibility - education has to be within safe physical reach, either by attendance at some reasonably convenient geographic location (e.g. a neighbourhood school) or via modern technology (e.g. access to a "distance learning" programme).

- Economic accessibility - education has to be affordable to all. This dimension of accessibility is subject to the differential wording of article 13 (2) in relation to primary, secondary and higher education: whereas primary education shall be available "free to all", states parties are required to progressively introduce free secondary and higher education.

(c) Acceptability - the form and substance of education, including curricula and teaching methods, have to be acceptable (e.g. relevant, culturally appropriate and of good quality) to students and, in appropriate cases, parents; this is subject to the educational objectives required by article 13 (1) and such minimum educational standards as may be approved by the state.

(d) Adaptability - education has to be flexible so it can adapt to the needs of changing societies and communities and respond to the needs of students within their diverse social and cultural settings.

A cursory look at the above-mentioned principles indicates that the right to education should be realised within the same ambit as traditional socio-economic rights such as the right of access to water, health and housing, which require a wholistic approaches aimed at ensuring that there exist no unnecessary impediments in the realisation of these rights (Mafunganyika, 2011: 202-228).

In Government of RSA v Grootboom the Constitutional Court as per Yacoob J held as follows;

"Our Constitution entrenches both civil and political rights and social and economic rights. All the rights in our Bill of Rights are inter-related and mutually supporting. There can be no doubt that human dignity, freedom, and equality, the foundational values of our society, are denied those who have no food, clothing, or shelter. Affording socio-economic rights to all people therefore enables them to enjoy the other rights enshrined in Chapter 2. The realisation of these rights is also key to the advancement of race and gender equality and the evolution of a society in which men and women are equally able to achieve their full potential" ( Government of RSA v Grootboom 2001 (1) SA 46 (CC) para 23).

"The right of access to adequate housing cannot be seen in isolation. There is a close relationship between it and the other socio-economic rights. Socio-economic rights must all be read together in the setting of the Constitution as a whole. The state is obliged to take positive action to meet the needs of those living in extreme conditions of poverty, homelessness, or intolerable housing. Their interconnectedness needs to be taken into account in interpreting the socioeconomic rights, and, in particular, in determining whether the state has met its obligations in terms of them" (Government of RSA v Grootboom 2001 (1) SA 46 (CC) para 24).

Therefore, in conclusion there is no doubt that the right to education is a justiciable human right in international law. Hence, the right to education in South Africa has to be given effect to within the prescripts of all other socio-economic rights including the promulgation of legislative frameworks and policies aimed at progressively realising the right to education within standards that are acceptable in the international community.

\section{Analysis of the Right to Education in the Light of the Reconstruction Development Programme and the White Paper on Education and Training}

As already stated above the right to education in South Africa, has been given effect to in numerous legislative frameworks and policies. The most important of these legislative frameworks are the Reconstruction and Development Programme and the White Paper on Education and Training. These legislative frameworks are founded on international human rights instruments and the Constitution. 


\subsection{The Reconstruction Development programme and the right to equal education}

After South Africa became a democratic State in 1994 numerous laws, policies, and programmes aimed at social upliftment were adopted and implemented. The RDP was one of the most prominent programmes that laid down guidelines for the equitable distribution and allocation of natural resources (RDP: 2.10.2.1). The central aim of the RDP was to ensure that the quality of life of all South Africans is improved. (RDP: 1.4) The RDP consisted of five key programmes that included developing human resources. A key component of this programme was to focus on education and training. (RDP: 1.3) The need for this programme was to transform the South African education system which was characterised by the following (RDP: 3.1.1.);

- The system was fragmented along racial and ethnic lines, and was saturated with the racist and sexist ideology and educational doctrines of apartheid.

- There was a lack of access or unequal access to education and training at all levels of the system. Vast disparities existed between black and white provision, and large numbers of people - in particular, adults (and more especially women), out-of-school youth, and children of pre-school age - have little or no access to education and training.

- There was a lack of democratic control within the education and training system. Students, teachers, parents, and workers were excluded from decision-making processes.

The RDP set platforms which enabled the government to realise the right to education within the principles set out in General Comment 13 to the ICESCR. The RDP set out certain principles that will ensure the proper realisation of the right to education which included the following;

- Education should be non-discriminatory

- Education must be directed to the full development of the individual and community, and to strengthening respect for human rights and fundamental freedoms.

- Education should be accessible.

- Education should be offered within acceptable national standards.

- Teachers, educators and trainers should be are able to understand and respond flexibly to the challenges of the new approaches to curriculum, method, delivery and certification which an integrated system of education and training demands.

Therefore, the RDP's vision for quality education indicates that the right to education is a justiciable socioeconomic right. Therefore, its realisation must conform to the standard afforded to other socio- economic rights.

\subsection{The White Paper on Education and Training and the right to equal education}

The White Paper echoed the sentiments contained in the RDP inter alia, transforming the education, and training system for the benefit of the country as a whole and its entire people. Similarly, to the RDP the purpose of the White Paper was aimed at creating an enabling environment in terms of which all citizens including the more vulnerable groups such as children, women, and disabled persons could benefit from the education system. In other words, the education system must be accessible to all citizens.

Another important aspect of the RDP apparent in the White Paper is the need for government to ensure that the educational standards are acceptable and are of high quality. In order to achieve acceptable educational standards, mechanisms should be put in place to ensure that the curriculum is of appropriate quality and to ensure that teachers and educators possess the necessary teaching skills.

\section{The Constitution and the Right to Education in Light of Education Specific Legislative Frameworks}

For the purposes of this article the authors will focus on sections 29(1) and (2) of the Constitution. The aim is to discuss section 29 of the Constitution in relation to the principles set out in the RDP and the White Paper as envisaged in article 13(2) of the ICESCR. The reliance on international law in the interpretation of the right to education is based on section 39(1)(b) of the Constitution which provides that when interpreting the Bill of Rights, a court, tribunal or forum must consider international law.

Section 29 of the Constitution reads as follows:

(1) Everyone has the right-

a. to a basic education, including adult basic education; and 
b. to further education, which the state, through reasonable measures, must make progressively available and accessible.

(2) Everyone has the right to receive education in the official language or languages of their choice in public educational institutions where that education is reasonably practicable. In order to ensure the effective access to, and implementation of, this right, the state must consider all reasonable educational alternatives, including single medium institutions, taking into account-

a. equity;

b. practicability; and

c. the need to redress the results of past racially discriminatory laws and practices.

(3) Everyone has the right to establish and maintain, at their own expense independent educational institutions that-

a. do not discriminate on the basis of race;

b. are registered with the state;

c. maintain standards that are not inferior to standards at comparable public educational institutions

(4) Subsection (3) does not preclude state subsidies for independent educational institutions.

As already indicated South Africa is a signatory to the ICESCR and has ratified amongst others the UDHR and the CRC. As a result, international law must be considered in measuring whether or not the state has complied with its international obligations in the realisation of the right to education as entrenched in section 29(1) and (2) of the Constitution.

Therefore the discussion centers on the effective realisation of the right to education in relation to availability, accessibility, acceptability, and adaptability.

\title{
4.1 The requirement of availability in South Africa
}

The first requirement requires that the right to education be made available to citizens. Section 29(1)(a) provides that everyone has the right to a basic education, including adult basic education. This subsection contemplates a minimum core approach to the realisation of the right to education. (Pieterse 2006:481) argues that the minimum core of a right represents a 'floor' of immediately enforceable entitlements from which progressive realisation should proceed. In other words the minimum core approach does not cater for any internal limitations of a right. The minimum core approach only allows limitations of general application.

In Governing Body of the Juma Musjid Primary School v Essay N.O the Constitutional Court per Nkabinde J held as follows;

\begin{abstract}
"Unlike some of the other socio-economic rights, this right is immediately realisable. There is no internal limitation requiring that the right be progressively realised within available resources subject to reasonable legislative measures. The right to a basic education in section 29(1)(a) may be limited only in terms of a law of general application which is reasonable and justifiable in an open and democratic society based on human dignity, equality and freedom" ( Governing Body of the Juma Musjid Primary School v Essay N.O 2011 (8) BCLR 761 (CC) para 37)
\end{abstract}

Therefore any limitation except for a general limitation violates the principle of availability as envisaged in international law. Article 26(1) of the UDHR provides that "everyone has the right to education" and that "education shall be free, at least in the elementary and fundamental stages. Therefore the right to basic education is not dependent on the availability of state resources like the rights of access to housing and other section 27 rights (Seloane, 2003: 140-141; Arendse, 2011:97-127).

The content of the right to education was recently confirmed in the case of Section 27 v Minister of Education and another where the court per Kollapen J held as follows;

"the provision of learner support material in the form of text books, as may be prescribed is an essential component of the right to basic education and its provision is inextricably linked to the fulfillment of the right. In fact, it is difficult to conceive, even with the best of intentions, how the right to basic education can be given effect to in the absence of text books" (Section 27 and Others v Minister of Education and Another 2013 (2) SA 40 (GNP) para 25)

Therefore, the principle of availability is an all encompassing principle and requires more than buildings. Hence, the state is obligated to ensure that before an establishment is determined as a school the requirements set out in section 5A of the South Africa Schools Act 84 of 1996 (SASA) are satisfied. 


\subsection{The requirement of accessibility in South Africa}

The second requirement is accessibility which includes economic accessibility, physical accessibility and nondiscrimination. In so far as accessibility to education is concerned the state has taken the minimum necessary measures to ensure that education is economically accessible to the majority of the citizens. In South Africa, numerous legislative frameworks make provision for exemption from the payment of school fees by parents. Therefore, parents or caregivers can apply for school fees exemption in terms of section 39(4) of SASA. In terms of section 39(7) of SASA no fee public schools can be identified by the member of the executive on directions of the minister of education.

The amended National Norms and Standards for School Funding adopted in terms of section 35 of SASA makes provision for partial and full exemption of school fees provided the parents meet the criteria for exemption. Regulation 4 of the Regulations to the Exemption of Parents from the payment of school fees of 2006 provides that parents must apply annually to be exempted from payment of school fees. Automatic exemptions from payment of school fees are also available to persons listed in regulation 1(a)- (d) which includes;

- Persons responsible for a child in a foster home, youth care center, place of safety or orphanage

- A person who is a kinship caregiver of an orphan or a child who has been abandoned by his or her parents and is without any visible means of support.

- A person who receives a social grant on behalf of a child

- A child who heads a household.

Therefore, no learner may be refused admission to a school on basis of lack of and non-payment of school fees.

The state has also taken reasonable measures in ensuring the higher education is economically accessible by enacting the National Student Financial Scheme Act 56 of 1999. The purpose of the Act is to provide financial aid to eligible students who meet the criteria for admission to a higher education programme. The financial aid is in the form of loans and bursaries. The loans are recoverable when the student completes his or her studies as envisaged in chapter 4 of the Act.

Physical accessibility to schools is a huge challenge in South Africa. This often leads to parents establishing illegal schools as seen in the Selowe primary saga in Silvermine, Limpopo Province where parents due to the fact that the nearest schools were between 4-6kilometers decided to establish a makeshift school in their area. Although measures have been taken by various provincial education departments to provide school transportation, there is a need for a single uniform school transportation system. As a result, the state is in the process of reviewing the National Scholar Transport policy of February 2009.

The envisaged purpose of the policy is to ensure the provision of a transport service that caters for the needs of scholars. The policy is aimed at providing transportation for learners from grades $\mathrm{R}$ to 12 living more than 3 kilometers from the nearest schools. According to the Minister of Basic Education Angie Motshekga, the government has completed the review of the National Scholar Transport Policy. Therefore, when the policy is finally enacted it will give effect to one of the most fundamental aspects of the right to education as envisaged in section 29(1) of the Constitution.

Another aspect of accessibility is non-discrimination. As already stated above both the RDP and the White Paper has as their aim that education be made accessible to the most vulnerable citizens namely, the youth, women, children and people with disabilities. As a result, the Education White Paper 6: Special Needs Education, July 2001(Education White Paper 6) was adopted to give effect to the vision of the RDP and White Paper which recognised the double standard discrimination of people with disabilities.

According to the Education White Paper 6, apartheid special schools were organised according to two segregating criteria, race, and disability. In accordance with apartheid policy, schools that accommodated white disabled learners were extremely well-resourced, whilst the few schools for black disabled learners were systematically underresourced. Therefore, the purpose of the Education White Paper 6 was to lay a platform aimed at (van Rooyen, Newmark \& Le Grange 2003: 167-189);

- Systematically moving away from using segregation according to categories of disabilities as an organising principle for institutions.

- Basing the provision of education for learners with disabilities on the intensity of support needed to overcome the debilitating impact of those disabilities.

- Placing an emphasis on supporting learners through full-service schools that will have a bias towards particular disabilities depending on need and support.

- Directing how the initial facilities will be set up and how the additional resources required will be accessed. 
- Indicating how learners with disability will be identified, assessed and incorporated into special, full-service and ordinary schools in an incremental manner.

- Introducing strategies and interventions that will assist educators to cope with a diversity of learning and teaching needs to ensure that transitory learning difficulties are ameliorated.

- Giving direction for the Education Support System needed.

- Providing clear signals about how current special schools will serve identified disabled learners on site and also serve as a resource to educators and schools in the area.

Furthermore, section $12(5)$ of SASA provides that the member of the executive Council must take all reasonable measures to ensure that the physical facilities at public schools are accessible to disabled persons. Regulation 22 of the Admission Policy for Ordinary Public Schools adopted in terms of section 3(4)(i) of the National Education Policy Act 27 of 1996 provides that the rights and wishes of learners with special education needs, must be taken into account at the admission of the learners to an ordinary public school. The South African Schools Act, 1996 requires ordinary public schools to admit learners with special education needs, where this is reasonably practical. Schools are encouraged to make the necessary arrangements, as far as practically possible, to make their facilities accessible to such learners.

The above-mentioned legislative frameworks gives effect not only to the right to education as entrenched in the section 29 of the Constitution but also to the rights to equality and human dignity entrenched in sections 9 and 10 of the Constitution (Boezaart, 2012: 458).

\subsection{The requirement of acceptability in South Africa}

The third requirement envisaged is that education must be acceptable. The acceptability relates not only to the curriculum taught but also that the teaching methods must be acceptable and that both the curriculum and teaching methods must be culturally acceptable. According to Curriculum News July 2012, a Department of Education newsletter aimed at bringing updates on curriculum changes, learning barriers can be caused by teaching methods. Moreover, the 2011 Guidelines for responding to learner diversity in the classroom through curriculum and assessment policy statements recognise the barriers to learning arising from the school curriculum and include the following aspects of the curriculum;

- the content

- the language

- classroom organisation

- teaching methodologies

- pace of teaching and time available to complete the curriculum

- teaching and learning support materials and assessment.

Therefore, teachers should be sensitive to learner diversity in the classroom. Learner diversity considers that there are learners from different socio-economic, language, cultural, religious, ethnic, racial, gender, sexual orientation, ability groups. Therefore to ensure that the curriculum is acceptable the teachers can;

- Adapt the curriculum in such a way that it is manageable for a wider range of learners.

- Ensure that teaching methods enable participation of all learners in learning. This can be done by scaffolding and flexible groupings. Scaffolding refers to the personal guidance, assistance, and support that a teacher, peer, or task provides to a learner. Flexible groupings refer to the placing of learners in groups according to the task at hand.

Therefore, such a leaner- oriented approach to teaching and learning not only caters for the learners' right to education but also for their socio-cultural diversity.

\subsection{The requirement of adaptability in South Africa}

Finally, education must be adaptable. In simple terms education must keep in pace with the changing social, technological and cultural values and be adaptable to learner needs. The South African government has over the years seen a need to focus on the core functions of higher education, namely: research, teaching and the curriculum, enhancing research capacity, professionalising teaching and learning, and conducting comprehensive reviews of the curriculum (Luescher and Symes, 2003).

The Education White Paper 3- A Programme for Higher Education Transformation GN 1196 in GG 18207 of 15 August 1997 (Education White Paper 3) echoes the sentiments of the RDP on societal transformation. The RDP provided that the underlying approaches of these programmes is that education and training should be available to all from cradle 
to grave. The RDP takes a broad view of education and training, seeing it not only as something that happens in schools or colleges, but in all areas of our society - homes, workplaces, public works programmes, and youth programmes and in rural areas (RDP: 1.4.5).

Although the Education White Paper 3 relates to the purposes of higher education, it is important in the explanation of the requirement of adaptability as envisaged in section 29 of the Constitution. The Education White Paper 3 outlines amongst others the following purposes of higher education;

- To meet the learning needs and aspirations of individuals through the development of their intellectual abilities and aptitudes throughout their lives. Higher education equips individuals to make the best use of their talents and of the opportunities offered by society for self-fulfillment. It is thus a key allocator of life chances an important vehicle for achieving equity in the distribution of opportunity and achievement among South African citizens.

- To address the development needs of society and provide the labour market, in a knowledge-driven and knowledge-dependent society, with the ever-changing high- level competencies and expertise necessary for the growth and prosperity of a modern economy. Higher education teaches and trains people to fulfill specialised social functions, enter the learned professions, or pursue vocations in administration, trade, industry, science and technology and the arts.

- To contribute to the socialisation of enlightened, responsible and constructively critical citizens.

- To contribute to the creation, sharing and evaluation of knowledge. Higher education engages in the pursuit of academic scholarship and intellectual inquiry in all fields of human understanding, through research, learning, and teaching.

In 2005, the South African government adopted the Outcomes Based Education (OBE) curriculum in an effort to enhance a child (learner)-centred approach (Meier, 2003: 223-229). The outcomes based curriculum was aimed at providing equal and adequate educational opportunities to all South Africans, and in the process also developing thinking, problem-solving citizens (Kaminsky, 2004). The then Minister of Education Naledi Pandor adopted the National Policy Framework for Teacher Education and Development in terms of sections 3(4)(f) and 7 of the National Education Policy Act 27 of 1996 in South Africa aimed at equipping teachers with the necessary skills to meet the needs of a democratic South Africa in the $21^{\text {st }}$ century. In other words teacher development must be aimed at ensuring that the learners are offered good quality education. Therefore, a flexible and adaptable education not only enhances the ability to learn but also equip learners with field (work) required skills.

\section{Conclusion}

The Constitution requires quality education to be provided equally and fairly. For this reason the courts have pronounced in a number of cases that failure to provide quality education violates the constitutional right to equality and as such results in unfair discrimination. In Matukane v Laerskool Potgietersrus 1996 SA 223 (T), the court held that the refusal by the school to admit black children on the basis of their language constitute unfair discrimination on the ground of language and race. There are several other challenges which prevent and/or hamper the full realisation of the right to education such as maladministration and corruption, continuous changing of the education curriculum without providing proper training to teachers etc.

Finally, the state must realise the right to education in an acceptable manner that gives effect to its international obligations and its obligations in terms of section 7 of the Constitution which provides that the State must respect, protect, promote, and fulfill the rights in the Bill of Rights.

\section{References}

Arendse L. (2011). The obligation to provide free basic education in South Africa: An international law perspective. Potchefstroom Electronic Review, 14(6): 97-127.

Boezaart T. (2012). A constitutional perspective on the rights of children with disabilities in an educational context. South African Public Law, 27(2): 455-472.

Christie P (1991). The right to learn: the struggle for education in South Africa. (2nd ed) (1991). Pretoria: Ravan Press.

Deegan H. (2001). The politics of new South Africa, Apartheid and after. (1st ed) (2001). South Africa: Pearson.

Fataar A. (1997). Access to schooling in post - apartheid South Africa: Linking Concepts to context International Review of Education, 43(4):331-348.

Franz GH. (1956). Aims of Bantu Education. Bantu Education Journal, 2(1): 5-8.

Harber C. (1997). Education, Democracy, and Political Development in Africa. (1st ed). United Kingdom: Sussex Academic Press. 
Hartshorne K.B. (1992). Crisis and Challenge: Black Education 1910-1990 (1st ed). New York: Oxford University Press.

Kaminsky S. (2004), Fostering Critical thinking through intervention in teaching and learning in the classroom', A Dissertation presented to the Higher Degrees Committee of Peninsula Technikon. [online] Available: http://dk.cput.ac.za/cgi/viewcontent.cgi?article $=1059 \&$ context=td_ptech 04 March 2014).

Khoza S (ed). (2007). Socio-economic Rights in South Africa: A Resource Book. (2nded). South Africa: Community Law Centre, University of the Western Cape

Liebenberg S \& Goldblatt B. (2007). The interrelationship between Equality and Socio-economic rights under the South Africa's Transformative Constitution. South African Journal on Human Rights, 22(2): 335-361.

Luescher TM \& Symes A. (2003). Council on Higher Education: The Transformation of Higher Education in South Africa: How Much Have We Achieved Perceptions of Policy Developments 1997-2003 and Outlook for the Next Five Years, 5TH Che Consultative Conference 12 November 2003. Available: http://www.che.ac.za/documents/d000052/che_ccresearch_report_Nov27_final.pdf (04 March 2014).

Mafunganyika G. (2011). The importance of environmental laws in housing developments: Lessons from the Diepsloot housing project. South African Public Law, 26(1): 202-228,

Meier C. (2003). The origins and development of child-centred education: Implications for classroom management. Educare, 32(1 \& 2): 222-239

Mphahlele MCJ \& Mminele SPP. (1997). Education through the ages (Book 3). Pretoria: Kagiso Trust.

Pieterse M. (2006). Resuscitating Socio-economic Rights: Constitutional entitlements to health care services. South African Journal on Human Rights, 22: 473-502

Seloane M. (2003). The right to education: Lessons from Grootboom. Law, Democracy \& Development, 7 (1): $137-169$

Sithole J. (1998). Democratic governance of public schooling in South Africa: A record of research and advocacy from the Education Policy Unit (University of Natal). Durban: Education Policy Unit.

Van Rooyen B, Newmark R \& Le Grange L . (2003). (De)constructing systems discourses in South Africa's Education White Paper 6: Special Needs Education. Acta Academica, 35(1): 167-189. 